\title{
Plasmaceller med inklusjonar
}

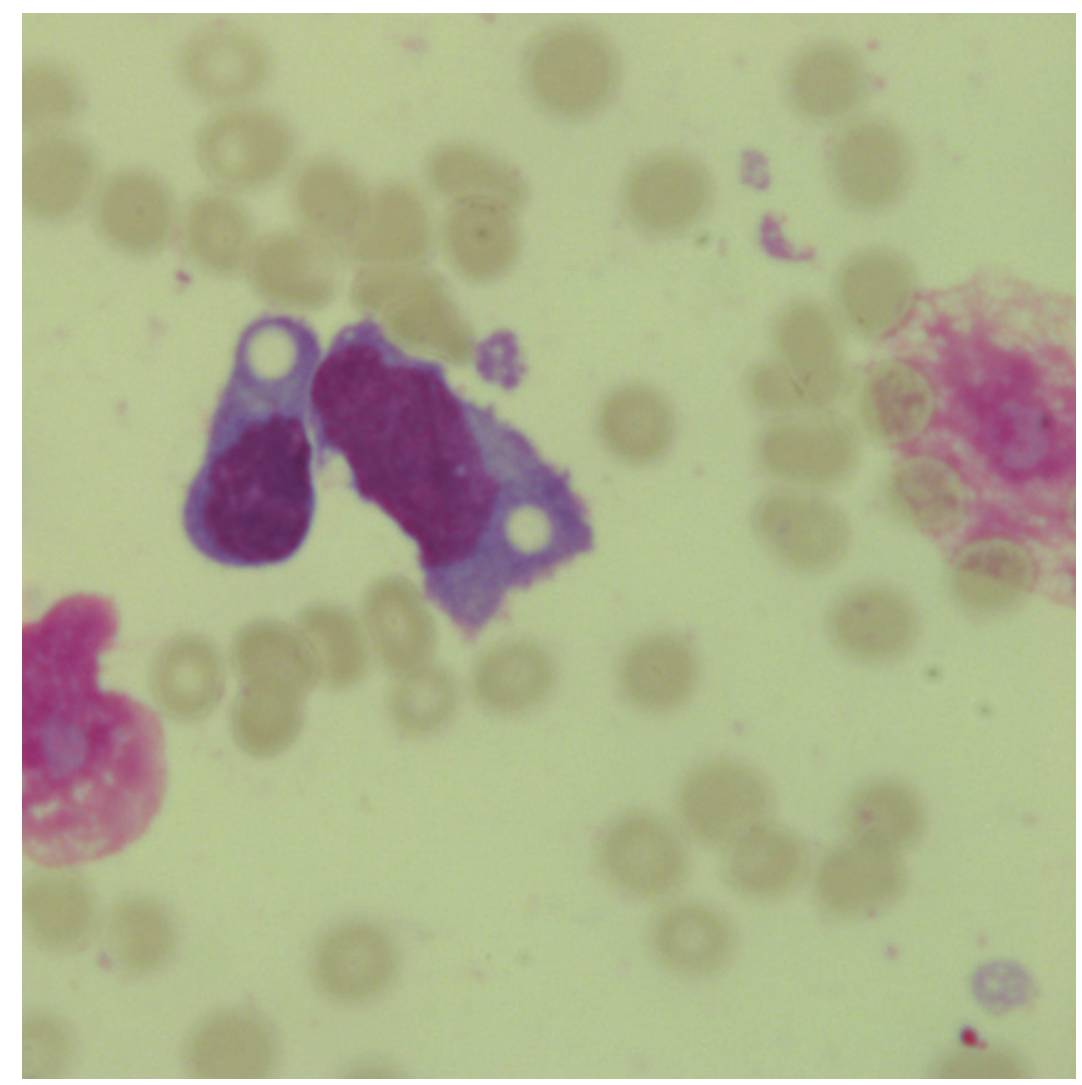

Ei kvinne i 60-åra vart diagnostisert med myelomatose som presenterte seg med osteolytiske destruksjonar av fleire virvelcorpora. Ho gjennomgikk initialt strålebehandling, med påfølgjande induksjonsbehandling og høgdose cellegiftbehandling med autolog stamcellestøtte (HMAS) (1). Sju månadar etter behandling utvikla ho redusert allmenntilstand, auka blødingstendens og aukande ryggsmerter. Ho vart på ny undersøkt med blodprøver og beinmargsaspirat. Ho hadde utvikla pancytopeni, stigning i M-komponent av type $\operatorname{IgA}$, og beinmargen viste ein massiv infiltrasjon av plasmaceller med umoden utsjånad (plasmablastceller), som utgjorde $>85 \%$ av kjernehaldige beinmargsceller. Fleire av cellene hadde store inklusjonar $\mathrm{i}$ cytoplasma som illustrert i bilete.

Fenomenet kallast Russell-lekamar, etter den skotske legen William Russell (18521940) som beskreiv fenomenet for første gong i 1890 (2). Russell-lekamar er karakterisert av eit distendert endoplasmatisk retikulum i plasmaceller som har ein uttalt produksjon av immunoglobuliner. I enkelte tilfelle kan det vere fleire Russell-lekamar i ei celle, og cella blir då kalla ei Mott-celle. I kontrast til Dutcher-lekamar som omgir cellekjernen, ligger Russell-lekamar i cytoplasma.

Russell-lekamar har vore beskrive i Bcelleneoplasier som myelomatose og lymfom. I tillegg kan dei forekomme ved M-komponent av usikker signifikans og i reaktive plasmaceller. Inklusjonar er ikkje patognomonisk for malign sjukdom, men heller ein defekt i utskillinga av unormale immunoglobuliner (3). Unormale inklusjonar i cytoplasma kan indikere patologi og bør medføre utredning med tanke på underliggjande sjukdom.

Pasienten fekk behandling med ein kombinasjon av tre medikament: bortezomib, thalidomid og deksametason. Dette ga klinisk respons med betring $\mathrm{i}$ allmenntilstand og regress av ryggsmerter. Det var også reduksjon av M-komponent og stigning i perifere blodverdiar, sjølv om pasienten forblei lett anemisk og trombocytopen under behandlinga.

\section{Pasienten har samtykt til publisering.}

\section{Håkon Reikvam}

hakon.reikvam@helse-bergen.no

Aymen Ahemd Bushra

Medisinsk avdeling

Haukeland universitetssjukehus
Håkon Reikvam (f.1978) er ph.d. og lege i spesialisering $\mathrm{i}$ indremedisin og i hematologi. Forfattaren har fylt ut ICMJE-skjemaet og oppgjev ingen interessekonfliktar.

Aymen Ahemd Bushra (f.1968) er ph.d., spesialist $\mathrm{i}$ indremedisin og $\mathrm{i}$ hematologi og seksjonsoverlege.

Forfattaren har fylt ut ICMJE-skjemaet og oppgjev ingen interessekonfliktar.

\section{Litteratur}

1. Wisløff F, Tangen J-M, Brinch L et al. Høydosebehandling med autolog stamcellestøtte - endelig et fremskritt ved myelomatose. Tidsskr Nor Lægeforen 2001: 121: 2402-6.

2. Russell W. An address on a characteristic organism of cancer. BMJ 1890; 2: 1356-60

3. Kopito RR, Sitia R. Aggresomes and Russell bodies. Symptoms of cellular indigestion? EMBO Rep 2000: 1:225-31. 